see any justification in supplying him from a fund of small subscriptions given, presumably, by a treeloving public.

In a brief note elsewhere "To Intending Planters", by H. E. Seaton, the sound advice is given, in deciding upon planting schemes, to remember that "pure woods of alien trees are not modern practice; but that mixed woods of trees which do well locally are likely to succeed and are fairly fool-proof". How often has this been forgotten, even by those professing forestry knowledge. "Tree Shelter for Cattle", by S. F. B. Lane, is a muchneeded reminder to farmers of the dangers being introduced in many parts of Britain by the indiscriminate tree felling which is taking place. Not only cattle, but also crops will suffer from the resultant exposure. An interesting article by H. E. Seaton on "Sewage and Civilization" (reprinted from the Rotary Service, Nov. 1940) sums up research work carried out by, among others, Dr. McCarrison and Sir Albert Howard in connexion with obtaining the present food for man and beast by a future suitable treatment of soils.

\section{The British Empire Naturalists' Association}

THe twentieth issue of the quarterly bulletin of the British Empire Naturalists' Association contains its usual summary of current field records and also the interesting announcement of the revival in octavo form, as in the War of 1914-18, of its well-known journal Country-Side, which had to be suspended at the outbreak of war. This decision is made possible with the very considerable-perhaps unexpectedinterest in field natural history that has been maintained in Great Britain despite the War, and often in the most heavily raided centres like London and Merseyside. The first issue of the new abbreviated form of this journal is expected in December.

Among botanical records in the autumn issue of the bulletin are creeping bellflower $(C$. ranunculoides) and willow-leaved spirrea (S. salicifolia) in the Cotswolds, thorn-apple (Datura) spreading over bomb craters in Kent and greater spearwort at Chippenham, Wiltshire. Entomological records show a very wide distribution of the clouded yellow butterfly during its immigration from the Continent this summer, records extending into Scotland. The pale clouded yellow is recorded from Cheshire, several white admirals from the Borough Green area of Kent and the Ruislip area of Middlesex, high brown fritillaries from the west Lancashire dunes, and the marbled white at Chippenham, Wiltshire. Ornithological reports include the black-necked grebe, white wagtail and shoveler nesting in Cheshire, and little gull, spotted redshank, greenshank, and sandwich tern on migration; grasshopper warbler nesting in Lancashire, and the little gull and red-necked phalarope on migration.

\section{Future of Telecommunications}

Is an address before the London Students' Section of the Institution of Electrical Engineers on October 15, Dr. W. G. Radley, of the Post Office Research Station at Dollis Hill, spoke on Telecommunications of the future. He pointed out that in 1914, although wire telephony had been in use for about forty years and had become an important factor in the social and business life of urban communities, the loss in speech power during transmission imposed definite limits to long-distance conversations. These limits disappeared as a result of the general introduction of thermionic valve amplifiers. Later on, the longdistance circuits which became possible were made cheaper by the development of systems of carriercurrent telephony, culminating in a standard system providing twelve speech channels over one pair of wires. A novel form of co-axial cable followed. This was capable of transmitting television or providing several hundred speech channels over two conductors. In the meantime, the transmission of speech by radio had made world-wide telephony possible. Each of these developments was the result of a long period of experimental work.

From the position of research work in 1939 , it is possible to hazard a guess at the nature of the telephone system during the post-war period. The disappearance of metallic conductors, and the develop. ment of long-distance speech transmission by means of what is virtually guided radio waves, is a future possibility. Research into the nature of speech sounds has made it possible recently to construct a machine which will speak under the control of an operator at a keyboard. An extension of this idea suggests the possibility of analysing speech in a local circuit, transmitting signals over the long-distance line corresponding to the results of the analysis and at the distant end automatically reconstructing the speech. The frequency band necessary for transmission of the signals over the long-distance line is very much narrower than that necessary for ordinary telephony, and this would enable more circuits to be obtained from long expensive submarine telephone cables. Improvements during the post-war period would probably lead eventually to the disappearance of telephone operators, except for special services. Improved fidelity of response of microphones and telephone receivers was foreshadowed, but no immediate change in principle.

\section{The Royal Observatory, Cape of Good Hope}

THE report for 1940 of H.M. Astronomer at the Cape of Good Hope illustrates how astronomical work in the belligerent countries is being affected even though they may be far removed from the present scene of hostilities. Half the observing staff at the Cape is now engaged on non-astronomical duties, this at a time when so many observatories in Europe have perforce suspended work. Nevertheless the depleted staff is doing its best to secure such observations as cannot be replaced by any made at a later date. Meridian observations of the moon have been started, in view of the possible loss of European obsèrvations, and volunteers have come to the rescue in observing occultations. Photographic work has been somewhat precarious owing to delays in the delivery of plates, but few photographs have been lost, and the position has been eased by a modification of the programme of routine 
solar observations which supplements that still being carried on at Greenwich. Work on the Reversible Transit Circle continues on a somewhat reduced scale, and the photometric observations are now sufficiently far advanced to make possible the construction of a framework of stars of magnitudes between 7 and 10 to which the magnitudes of the zone stars can be referred. With the 1940 batch of parallaxes the Observatory now enters the very restricted list of stations at which the distances of more than a thousand stars have been determined trigonometrically.

The section of the report which will be read with perhaps the greatest interest concerns the total solar eclipse of October 1, 1940. The main part of the programme was to measure the gravitational deflexion of light in the sun's field-the Einstein effect. The Greenwich expedition which was to have cooperated in this work was cancelled at the outbreak of war, and the entire programme was carried through, as planned, by the Cape staff. It is disappointing to have to record total failure in this part of the work. The field of stars close to the eclipsed sun was known beforehand to be a poor one; but eclipses are so few and far between that the attempt seemed justified. In fact, the lessened exposure time and reduced aperture necessary to prevent fogging of the plates by the rather bright sky, combined with the poor daytime 'seeing' on the Karroo to prevent any stars showing on the negatives at all. Astronomers all over the world will sympathize with H.M. Astronomer and his staff in this disappointment, particularly as observing conditions were otherwise good. Their sole compensation was in securing the only largescale photographs of the corona obtained during this eclipse-photographs which, though interesting and indeed important, represent a most inadequate reward for months of work.

\section{Prevention of Blindness}

IN its annual report for 1940 the United States National Society for the Prevention of Blindness stresses the increase in eye accidents brought about by extension of industrial production made necessary by national defence. Many firms are now using the industrial film known as "The Eyes Have It", which has been made available to the Society without cost by the Pullman Society. The Society is now planning an evaluation of vision-testing procedure used with school children and pre-school children in the hope of establishing a uniform procedure. During 1940 the National League for Nursing Education began a study of nursing education in sight conservation in co-operation with the Society. The Society has also arranged to co-operate with similar organizations in Latin America, has prepared an exhibition on glaucoma, and has continued its campaign to reduce blindness caused by venereal disease and fireworks.

\section{Earthquake in the Argentine}

The United States Coast and Geodetic Survey, in co-operation with Science Service and the Jesuit Seismological Association, has determined the pro- visional epicentre of the earthquake of July 3 at 7h. $11 \cdot 7 \mathrm{~m}$. U.T. as being at lat. $33^{\circ} \mathrm{S}$., long. $68^{\circ} \mathrm{W}$. The calculations have been based on reports from eleven seismograph stations. The epicentre is situated near the railway line about midway between Mendoza and San Luis. Activity in this region has been much less severe and more infrequent than between 1750 and 1910. There was a strong earthquake at Mendoza on May 22, 1782, though this was surpassed by the terrific shock in the same area which caused widespread destruction on March 20, 1861. Prior to this latter shock, San Luis was destroyed on April 9, 1849. Further intense shocks were experienced in both places up to about 1910 . It may be that, following the catastrophic shock of January 24, 1939, at Chillan in Chile (Nature, Feb. 11, 1939, p. 230), the centre of activity has moved eastwards. The earthquake of July 11, 1941, at 1 . $16^{\cdot 6 \mathrm{~m}}$. U.T. had its epicentre in the Pacific Ocean between the Galapagos Islands and the Isthmus of Panama.

\section{University of Cambridge}

UNDER the will of Mr. Alfred Corner, of Stavarton Road, Brondesbury Park, London, who died in 1934, the University has received $£ 1,440$ for the sole purposes of the Cambridge University Biochemical Laboratory. The full value of the bequest of which this is an instalment may approach $£ 1,800$.

The professorship of animal pathology will be vacated on December 31 by the resignation of Prof. T. Dalling.

\section{Announcements}

Sir Henry Dale, president of the Royal Society, has been awarded the Gold Medal for 1941 of the Royal Society of Medicine. The Medal is given triennially for "valuable contributions to the science and art of medicine".

The Right Hon. Lord Chatrield, recently Minister for the Co-ordination of Defence, has been elected president of the Institution of Naval Architects in succession to the late Lord Stonehaven.

Mr. R. A. WAtson WAtr, scientific adviser on telecommunications to the Air Ministry, has been elected president of the Association of Scientific Workers in succession to Prof. F. G. Donnan.

IN connexion with the fiftieth anniversary of the University of Chicago which was celebrated a short time ago, the sum of $9,200,000$ dollars has already been subscribed by the citizens of Chicago towards an anniversary fund of $12,000,000$ dollars. It is planned to raise the balance over a period of five years.

Dr. P. C. Koller and C. Auerbach, of the Institute of Animal Genetics, University of Edinburgh, writing with reference to their letter "Chromosome Breakage and Sterility in the Mouse" which appeared in NATURE of October 25, p. 501, wish to withdraw the last two sentences in the first paragraph of column 2 beginning with "We can confirm . . ." 